\title{
Impact of Non Performing Loan on Bank Performance in Nigeria A Case Study of Selected Deposit Money Banks
}

\author{
Eniafe Abimbola \\ Coordinator Christ Embassy Obawole \\ Program Analyst, New Towns Development Authority \\ Director, Vip Koncepts Consulting
}

\begin{abstract}
The fundamental role of Deposit money banks (Dmbs) is to act as intermediary between surplus unit (supply side) and deficit unit (demand side) of fund. Dmbs objectives are profitability, growth in assets and customer base. To achieve these Dmbs grant loans and advances to individuals, business organizations and government. Loan default could be rampant resulting from low quality of assets, high non-performing risk assets (credit risk) that may result in huge loan losses and thus reduction in bank profitability. This study investigates the impact of non-performing loans on Money deposit banks' performance in Nigeria. Hypotheses were set and data were sourced from secondary data. The study used the confirmed ECM model (via residual and least square method of analyses. The results revealed that non performing loans have impact Deposit Money Banks performance within the period of study; whereas, the impact of the individually independent variables (net interest margin and deposit to loan.) varied. The study recommends, amongst others that, effective credit policy that is reflected in flexible tenure, restructuring of credit terms and conversion should be adopted in the Deposit Money banks. This policy could help reducing the tempo of nonperforming loan, such that as return on equity is increasing, the possibility of default would decline considerably.
\end{abstract}

Key Words: Credit risk, Bank specific factors, Bank Loan and advances,

\subsection{Background to the Study}

Banks and financial institutions in a country act as intermediary between surplus unit (supply side) and deficit unit (demand side) of fund. Nigeria's financial system is a conglomerate of various markets, instruments, operators, and institutions that interact within the economy to provide financial services. Nigeria with versatile financial system comprises of 2991 bureau de change, 21 commercial banks, 6 development finance institutions, 5 discount houses, 64 finance Companies, 5 merchant banks, 942 micro-finance banks, 1 non-interest bank, and 36 primary mortgage institutions (CBN, 2016). Developing the financial sector, therefore, became an important development target for countries. Banks grant loans and advances to individuals, business organizations as well as government in order to enable them undertake investments and other development activities as a mean of contributing toward the economic growth in general and aiding economic development in particular. But in time of economic recession, loan default could be more rampant resulting from low quality of assets, high non-performing risk assets (credit risk) that may result in huge loan losses and thus reduction in bank profitability. However, if such assets do not generate any income, the banks` ability to repay the deposit amount on the due date would be in jeopardy. Therefore, banks with such asset would become weak and such weak banks will lose the faith and confidence of their customers. Ultimately, unrecoverable amounts of loans are written off as non-performing loan (Sere-Ejembi, Udom, Salihu, Atoi, and Yaaba., (2014)). Thus, since nonperforming loans had an adverse effect on the banking sectors survival, the cause for NPLs should be given due consideration. In Nigerian financial system, non-performing loans (NPLs) refer to loans which for a relatively long period of time do not generate income. This implies that the principal and or interest on these loans have been left unpaid for at least 90 days (Atoi, 2018). NPLs have become a critical issue of discourse in finance literature because of the close link between banking crises and massive accumulation of it. Its causes vary in different countries, which might be due to situational factors such as the level of economic condition in which the banking sectors are operating and also bank level factors. Macroeconomic variables are external forces of determinants of credit assets quality and banks specific policies, staff quality, morale, asset management mechanism and so on are internal drivers of banking performance.

Banking sector in Nigeria has faced a lot of problems, the most destructive problems is the huge and ever increasing amount of NPLs which has influence on banks' efficiency and growth as well as endanger the growth and development of the Nigerian economy. The magnitude of nonperforming loans in Nigeria increased from N260.19 billion as at end December 2003 to N2.9 trillion as at end December 2009 then reduced to $\$ 649.63$ billion at the end of December 2015 (CBN, 2016). 
Huge NPLs may negatively affect the level of private investment, increase deposit liabilities and constrain the scope of bank credit to the private sector. Also they can negatively affect private consumption which may lead to economic contraction. The phenomenal increases necessitate the investigation into the sensitivity of bank performing and nonperforming loans to bank specific and macroeconomic factors in Nigeria.

\subsection{Statement of the Problem}

The business of banking has to do with lending which involves the risk that the borrower will not pay back the loan as promised, and paying a fixed rate of interest on term deposits. This involves the risk that lending rates will drop, leaving the bank earning less on its investments than it is paying out on deposits. This paper attempts to identify the impact non-performing loan on bank performing in Nigeria.

Credit risk management is complex and unpredictable in an environment which is peculiar to the banking industry. Yet banks grant loans and advances to individuals, business organizations as well as government in order to enable them undertake investments and other development activities as a mean of contributing toward the economic growth in general and aiding economic development in particular. In the process, loan defaults are generated resulting from low quality of assets, high non-performing loans (NPLs) that resulted to loan losses and reduction in bank profitability. These NPLs hamper economic growth and reduce the economic efficiency. Against this background, this work will evaluate the determinants of non-performing loans and its effect on bank performance between 2006 to 2017.

\subsection{Objectives of the Study}

The broad objective of this study is to investigate the impact of non-performing loan on bank performance in Nigeria. Other specific objectives are to;

1. Investigate the impact of non-performing loan on performance of selected Deposit Money Banks' in Nigeria

2. Investigate the impact of non-performing loan on profitability of selected deposit money bank in Nigeria.

\subsection{Research Questions}

The research questions drafted for this study are based on the specific objectives of the study, specified as follows;

1. What the impact of non-performing loan on Deposit Money Banks' performance in Nigeria?

2. what is the impact of non-performing loan on the deposit money bank's profitability?

\subsection{Research Hypothesis}

To proffer answers to the questions above, the following hypotheses are formulated and stated in null forms. This consciously provides a basis for deriving testable arguments.

1. Non-performing loans does not have significant impact on Deposit Money Banks' productivity in Nigeria

2. There is no significant relationship between non-performing loans and deposit money bank's Profitability in Nigeria.

\subsection{Significance of the Study}

The study is pervasively timely, especially since the Nigerian government is working towards achieving an optimal economic diversification which is essentially hinged on sound bank credit management. Therefore, findings of this study which detail the determinants of nonperforming and performing loan of commercial bank in Nigeria shall be beneficial to different stakeholders in banking sector (Deposit Money Banks and micro finance banks), monetary authority (Central Bank of Nigeria) and researchers. The findings of this study shall be used as definite inputs in developing regulatory standards regarding the lending policies of Deposit Money Banks in Nigeria.

This study shall sensitize the deposit money bank management to give due emphasis to the management of these identified variables and provide them with the understanding of activities that can enhance their loan performance.

\subsection{Scope and Delimitation of the Study}

This work is to examines the impact of NPLs on Deposit Money Banks (DMBs) in Nigeria between periods 2006 to 2017. These banks were selected based on their performance and are expected to have more experience on the lending activities. Explicitly, the study shall focus on determinants of NPLs of Dmbs development in Nigeria. Other possible factors that may influence the development of the banking sector such as financial literacy as well as culture or institutional factors shall not be included. These factors are beyond the scope of this study. Thus, this study focus on impact of NPLs on deposit money banks in Nigeria between the periods 2006 to 2017. 


\subsection{Organization of the Seminar Paper}

This study is organized into four (4) sections. The first sector starts with presenting background of the study, statement of the problem, objective of the study, significance of the study, scope and limitation of the study. The second section focuses on both theoretical and empirical review of related literature. The third sector deals with the research methodology, presentation of results and policy statement; the section four centers on summary of findings, conclusion, contribution to knowledge and recommendations.

\section{Section II: Literature Review}

\subsection{Introduction}

Bank denotes a financial institution dealing in money that is an institution that accept deposits of money, repay the same on demand and other related services. Therefore bank is a financial institution licensed to receive deposits and make loans. Banks may also provide financial services, such as wealth management, currency exchange and safe deposit boxes. But Verter, and Osakwe, (2015) defined banking as an industry that handles cash, credit, and other financial transactions. Banks provide a safe place to store extra cash and credit. They offer savings accounts, certificates of deposit and checking accounts. Banks use these deposits to make loans. These loans include home mortgages, business loans, and car loans. Banking is one of the key drivers of the any nations' economy. It provides the liquidity needed for private and public to invest for the future.

\subsection{Conceptual Frame Work}

There are fundamental economic roles banks are expected to perform. They are to act as financial intermediaries and facilitating the payment system for the purpose of ensuring an efficient allocation of the deposits in their custody. The notion of banking in the modern-day sense refers to the native laws and customs of the geo-political entities and unit making up the present day Nigeria (Nwankawo, 2005). Modern banking according Central Bank of Nigeria sourced (Bullion, 2006) can be said to have commenced in Nigeria during the second half of the nineteenth century; when Elder Dempster started the movement of money in specie from one part of the country to another in other to boost its shipping business. Thus, the banking industry predates Nigeria and her attainment of political independence.

Agada and Osuji (2013) defined banks as a financial institutions or intermediaries which mobilize deposits from the public and create deposit money by granting loans, advances and overdrafts to their clients and in the process earn profits on their investors' funds. This definition emphasizes the core functions of banks, namely, financial intermediation and provision of liquidity. Financial intermediation is the process performed by banks of taking in funds from a depositor and then lending them out to a borrower. The banking business thrives on financial intermediation abilities to lend out money at relatively high rates of interest while receiving money on deposit at relatively low rates of interest. The intermediation process involves the mobilization of deposit from surplus economic units and channeling same to deficit economic units in the form of loan and overdraft and this creates earning assets that enable the bank generate profits.

Modern banking institution was established in 1892 was when the first banking institution was established. This was the African Banking Corporation (ABC) which opened its first branch in Lagos as at 1892. Messrs Elder Dempster and company, a shipping firm based in Liverpool was instrumental. However, due to poor management, the bank experienced some initial difficulties which forced it to transfer its interest to Elder Dempster and company in 1893 (Bullion, 2014).

Onwe (2015) identified two characteristics that are common to financial services; fiduciary responsibility and two-way information flow, Beckett (2010) includes three additional characteristics that distinguish financial services. These are transparency of performance, uncertainty of outcome and poor comparability.

These banks transform into a systemic in the banking sector, the intervention of the Central Bank has also stabilized the liquidity position of the rescued banks, thus bringing the entire industry on a sound liquidity footing. In the process, the balance sheet of some banks expanded wholesome others came up with smaller size but healthier balance sheet. This then has opened a new chapter for banking in Nigeria- a kind of recommencement and a new phrase of earnings, growth and profitability. An assessment of the banks based on the CAMELS parameters representing Capital Asset Quality Management Quality, Management Quality, Earnings Quality, Liquidity and sensitivity to the market, provides a clear picture of the foundation for the new prospect and positive outlook As at end of 2010, the assessment by Central Bank of Nigeria placed the industry on a sound footing, indeed a significant improvement over the situation in 2007 (prior to the impact of the global financial crisis) and in 2009 when the crisis. In the current sound state of the health of banks in operation in Nigeria is a pointer to their readiness for the new spurt of growth and profitability. 
The usual drag on performance which are non-performing loans have been taken out of the way by AMCON and the sequel of recapitalization is also on course for the banks that suffered capital erosion.

Table 2.1: Summary of Bank's Activities between 2007, 2009 and 2010

\begin{tabular}{|c|c|c|c|}
\hline Parameter & 2007 & 2009 & 2010 \\
\hline $\begin{array}{l}\text { Capital Adequacy Ratio } \\
\text { (CAR-Minimum } \\
\text { prescribed is } 10 \% \text { ) }\end{array}$ & $\begin{array}{l}3 \text { banks failed to meet the } \\
\text { stipulated minimum, of } \\
10 \%\end{array}$ & $\begin{array}{l}11 \text { banks failed to meet } \\
\text { the prudent minimum of } \\
10 \%\end{array}$ & $\begin{array}{l}8 \text { banks failed to meet the } \\
\text { prescribed minimum-they } \\
\text { were the banks rescued by } \\
\text { the CBN }\end{array}$ \\
\hline Management Quality & $\begin{array}{l}\text { No concerns, every bank } \\
\text { showed strong performance } \\
\text { and potential. Many banks } \\
\text { complied with the } \\
\text { provision of the Code of } \\
\text { Corporate Governance; } \\
\text { errant banks were } \\
\text { sanctioned }\end{array}$ & $\begin{array}{l}\text { There was excessive risk } \\
\text { taking, weak risk } \\
\text { management, focus on } \\
\text { short term gains and lack } \\
\text { of management capacity } \\
\text { in several banks }\end{array}$ & $\begin{array}{l}\text { No corporate governance } \\
\text { issue and risk management } \\
\text { has been strengthen across } \\
\text { the industry }\end{array}$ \\
\hline Earning Quality & $\begin{array}{l}\text { There was improvement in } \\
\text { earnings although the } \\
\text { return on assets and return } \\
\text { on equity diminished as a } \\
\text { result of phenomenal } \\
\text { increase in total assets and } \\
\text { shareholders' fund }\end{array}$ & $\begin{array}{l}\text { Earning quality was } \\
\text { compromised by the } \\
\text { huge provisions that } \\
\text { banks had to make as a } \\
\text { result of excessive } \\
\text { exposure to capital } \\
\text { market oil and gas sector } \\
\text { and closed foreign credit } \\
\text { lines. }\end{array}$ & $\begin{array}{l}\text { Earning grew significantly, } \\
\text { as most problem loans were } \\
\text { purchased from the banks by } \\
\text { AMCON. }\end{array}$ \\
\hline Liquidity & $\begin{array}{l}2 \text { banks failed to meet the } \\
\text { liquidity ratio requirement. }\end{array}$ & $\begin{array}{l}3 \text { banks failed to meet } \\
\text { the liquidity ratio } \\
\text { requirement. Industry } \\
\text { average of } 35.3 \% \\
\text { exceeded the prescribed } \\
\text { minimum of } 25 \%\end{array}$ & $\begin{array}{l}\text { All banks met the prescribed } \\
\text { minimum liquidity ratio }\end{array}$ \\
\hline Sensitivity to Market & $\begin{array}{l}\text { Banks; balance sheet } \\
\text { became more rate sensitive } \\
\text { due to the massive growth } \\
\text { in risk assets and deposits. } \\
\text { This extended the } \\
\text { vulnerability of banks and } \\
\text { required them to strengthen } \\
\text { their risk management } \\
\text { capacity }\end{array}$ & $\begin{array}{l}\text { New supervisory regime } \\
\text { forced improvement in } \\
\text { risk management } \\
\text { capacity }\end{array}$ & $\begin{array}{l}\text { The systemic building of risk } \\
\text { management infrastructure } \\
\text { and capacity in line with the } \\
\text { new supervisory regime has } \\
\text { strengthened the banks in } \\
\text { handling market risks. }\end{array}$ \\
\hline
\end{tabular}

\section{Source:}

All the banks have consolidated their performance of 2010 by significant improvement in their third quarter 2011 results which show clearly that the prospects for earning generation are much brighter than 2008-2010 when the global crisis impacted the banking system and the CBN started the reforms. The major challenge facing the banks appears to be the conversion of earning into profit in the inflationary Nigerian business environment. Four banks were adjudge not able to recapitalized hence three of these banks were nationalized and one was taken over by African Capital Alliance Consortium, thus have the following as the remaining banks in Nigeria. Total emerged banks in Nigeria after the reforms are Citibank Plc, Diamond Bank Plc, Fidelity Bank Nigeria, First Bank of Nigeria, Guaranty Trust Bank, Stanbic IBTC Bank Nigeria Limited, Standard Chartered Bank, United Bank for Africa, Unity Bank Plc, WEMA Bank Plc, Zenith Bank Plc, Skye Bank Plc. Then Access Bank acquired Intercontinental Bank Plc, Ecobank Nigeria acquired Oceanic Bank Plc, Enterprises Bank Limited Fomerly Spring Bank, First City Monument Bank acquired FinBank and Sterling Bank acquired Equatorial Trust Bank. Other banks were nationalized with Bank PHB becoming Keystone Bank Limited and Afri BankPlc becoming MainStreet Bank Limited. 
Granting of credit facilities to customers is an objective of commercial banks since both parties stand to benefit from such transaction. However, the issues of faithfulness and unassessed investment risk have made the otherwise good relationship to become something worrisome. Scholars over the years have proffer ways and method of dealing with risks arising from bank operations and their conclusion is that management are expected to be proactive, that is to devise measures to identify any kind of risk that can result in undesirable outcomes that is managing a risk in advance is far better than waiting for its occurrence. Risk Management is a measure that is used for identifying, analyzing and then responding to a particular risk. It is a process that is continuous in nature and a helpful tool in decision making process.

Credit risk management in commercial banks is very important not only because of the financial crisis that the world is experiencing currently, but also as a crucial concept which determines banks' survival, growth and profitability. Because credit granting is one of the key sources of income generating activity in rural banks, the management of the risk related to credit affects the profitability of the banks. Hence adequate management of credit risk in financial institutions is critical for the survival and growth of any financial institutions. In the case of banks in developing economy, the issue of credit risk is of greater concern because of the higher levels of perceived risk resulting from some of the characters and high uncertainty in external business environment. Sufian and Parman, (2009) posit that financial institutions grow as they mobilize savings for productive investments through facilitating role in capital flows towards various sectors of the economy.

Nikolaidou and Vogiazas (2014) defined credit risk management as the combination of coordinated tasks and activities for controlling and directing risks confronted by an organization through the incorporation of key risk management tactics and processes in relation to the organization's objectives. It is important to note that risk management practices are not developed and aimed to eliminate risks altogether but they aim at controlling opportunities and hazards that may result in risk (Frank et al., 2014). Furthermore, Ekanayake, and Azeez (2015) opined that risk management practices also ensure that financial institutions must have strong and rational framework for decision making by which firm's objectives can be attained. But García et al., (2013) note that effective credit risk management practices have never been successful to eliminate the human element in making decisions about controlling risk.

Previous studies have noted that high credit risk controls (CRC) result in low chances of defaults (Ekanayake, and Azeez (2015)). Therefore, credit risk could be alleviated by utilizing danger based evaluating, contracts, credit protection, tightening and broadening (Ekanayake, and Azeez (2015). Sere-Ejembi, Udom, Salihu, Atoi and Yaaba, (2014) argued that intelligent and effective management of credit lines is a key requirement for effective credit management. Sere-Ejembi et al., (2014) observed that to minimize the risk of bad debt and over-reserving, banks ought to have greater insight into important factors like, customer financial strength, credit score history and changing payment patterns. Credit risk variation indicates the change in health of loan portfolio managed by bank resultantly performance of financial institution would also vary accordingly. If financial institutions are exposed to high risk loans, there would be accumulation of unpaid loans along with less profit.

Loan portfolio is not only considered as a largest asset as well as pre-dominate source to generate revenue but one of the biggest risk source for the financial institution's soundness and safety as well (Raluca-Ioana and Oaneab, 2014). Hence credit risk management is considered to be one of the road maps for soundness and safety of the sector through prudent actions as well as monitoring and performance. Basel, (2004) observed that despite all efforts made by the financial institutions number of problems increased significantly in both, emerging as well as matured economies of the world. Most important of all the risks associated to financial institutions is weak credit risk management, being a threat for the banking sector (Raluca-Ioana and Oaneab, 2014). There should be systematic distribution of loans according to well established credit policies and procedures provided by (Dayong Jing., David and Ali, 2016). Well formulated loan policy is beneficial for institutional performance. Hence it helps organizations to follow the same for risk management as well as fulfilling regulatory requirements (Akinlo, and Mofoluwaso, 2014). Loan review is a part of policy and is crucial, helping management in problem identification on regular basis to check either loan officers are following the policy in true letter and spirit or not. The review policy is better implemented by commercial bank hence they were easily able to top up loans in no time through use of modern technology unlike institutions (Onwe, 2015).

Loan appraisal is an application/request for funds, evaluated by financial institution. The aspects to be focused in appraisal includes: purpose of the client, need genuineness, repayment capacity of the borrower, quantum of loan and security. Loan appraisal plays important role to keep the loan losses to minimum level, hence if those officers appointed for loan appraisal are competent then there would be high chances of lending money to non-deserving customers. Collection procedure is a systematic way required to recover the past due amount from clients within the lawful jurisdiction. 
The collection aspects may vary from institution but those should be complaint to existing laws such as third party collection agencies may involve in a collection process. Credit management is the method by which you collect and control the payments from your customers. (Boldizzoni, 2014) described credit management as methods and strategies adopted by a firm to ensure that they maintain an optimal level of credit and its effective management. It is an aspect of financial management involving credit analysis, credit rating, credit classification and credit reporting. The volume of loans granted by a bank in a year may be a function of its internal characteristics such as size, deposit base, liquidity, credit policy and other internal factors, all of which may be said to fall though relatively, within the control of the bank. These policies are internal, but to a large extent mimic the general macroeconomic environment, such that the general loan behavior of most banks will be a reflection of the signals from the aggregate economy and money supply in the economy.

Credit risk is defined by Basel (1999) as the potential that debtor or counter party default in satisfying contractually pre-determined obligation according to the agreed upon terms. Careful look at the balance sheet of any Deposit Money Banks (DMBs) reveal that in Nigeria credit (loan and advances) are the largest single item in the assets structure. Apparently, loan and advances make up the major sources of the operating income in banks. In November 1990 the Central Bank of Nigeria issued a circular on "Prudential Guidelines" for licensed banks. The guidelines stipulated minimum requirements for assets classification and disclosure, provision of interest accrual and off balance sheet engagement (CBN Circular No. BSD/20/23 Vol.1 /11). The guidelines imposed new and far-reaching requirements in the classification of risk assets and provision for bad and doubtful debts. They emphasized the time recognition of determination in the quality of assets and the classification of credit facilities into "performing" and "non-performing" accounts. In the circular credit facility is deemed to be performing when the payment of both principal and interest are up-to-date in accordance with the agreed terms, while credit facilities should be deemed as "non-performing" when any of the following conditions existence

1. Interest or principal is due and unpaid for 90 days or more; and

2. Interest payments equals to 90 days or more have been capitalized, rescheduled, or rolled over, into a new loan (except where facilities have been reclassified as performing) the borrower must effect cash payment such that outstanding unpaid interest does not exceed 90 days.

Non- performing Loan (NPL) facilities are to be further classified into three categories as follows:

(a) Substandard: Where the interest or principal payments are in arrears for 90 days-180 days

(b) Doubtful: Where interest or principals payments are in arrears for 180 days to 360 days, and no perfected tangible security is in course of realization.

(c) Lost: Where interest or principal payments are in arrears for more than 360 days and no perfected tangible security is in the course of realization.

\subsection{Theoretical Framework}

\section{Transactions Costs Theory}

The theory was first developed by Schwartz (1974) is the anchor theory for this study. The theory infers that suppliers may have an advantage over traditional lenders in checking the real financial situation or the credit worthiness of their clients. Suppliers also have a better ability to monitor and force repayment of the credit. All these superiorities may give suppliers a cost advantage when compared with financial institutions. Three sources of cost advantage were classified by Petersen and Rajan (1997) as follows: information acquisition, controlling the buyer and salvaging value from existing assets. The first source of cost advantage can be explained by the fact that sellers can get information about buyers faster and at lower cost because it is obtained in the normal course of business. That is, the frequency and the amount of the buyer's orders give suppliers an idea of the client's situation; the buyer's rejection of discounts for early payment may serve to alert the supplier of a weakening in the credit-worthiness of the buyer, and sellers usually visit customers more often than financial institutions do.

\subsection{Review of Empirical Literature}

The relationship between financial development and economic growth has been explained by researchers using both firm level and industry level data across board, cross-section of countries. Makri, et al. (2014) identify the factors affecting NPLs of Euro zone's banking systems for 2000-2008 periods before the beginning of the recession. The study includes 14 countries as a sample out of 17 Euro zone countries. The variables included were growth rate of GDP, budget deficit (fiscal), public debt, unemployment, loans to deposits ratio, return on assets 
(ROA), and return on equity (ROE) and capital adequacy ratio. The study utilize difference Generalized Method of the Moments (GMM) estimation and found real GDP growth rate, ROA and ROE had negative relationship whereas lending, unemployment and inflation rate had positive significant effect on NPLs. However, ROA and loan to deposit ratio, inflation, and budget deficit did not show any significant impact on NPL ratio. Similarly, Carlos (2012) on macroeconomic determinants of the non-performing loans (NPLs) in Spain and Italy found inflation rate has insignificant effect on NPLs. Selma and Jouini (2013) conducted a study on three countries namely Italy, Greece and Spain for the period of 2004-2008 to identify the determinants of NPLs for a sample of 85 banks. The variables included both macroeconomic variables (GDP growth rate, unemployment rate and real interest rate) and bank specific variables (return on assets, loan growth and the loan loss reserves to total loans). It was found out that GDP growth rate, unemployment rate and real interest rate had positive significant effect on NPLs. However, ROA, loan growth and the loan loss reserves to total loans did not show any significant impact on NPL ratio.

Benyah (2010) investigated determinants of financial intermediary development in all African countries, by making use of cross sectional data and panel data techniques, for the period of 1975-2006. Financial intermediary development is quantified by a banking sector indicator, liquid liabilities $\left(\mathrm{M}^{3}\right)$, while the explanatory variables were trade openness, financial openness and GDP growth rate. Trade openness is measured as sum of exports and imports, as a ratio of GDP and financial openness is measured as sum of foreign assets and liabilities as a ratio of GDP. The cross sectional regression results showed that there is a positive relationship between trade openness and financial intermediary development. GDP growth rate and financial openness are not statistically significant in explaining financial intermediary development. Panel regression results also showed trade openness is important in explaining financial intermediary development, and financial openness negatively influences financial development. The GDP growth rate is insignificant.

The study of Saba et al.(2012) also investigated the bank specific and macroeconomic variables of nonperforming loans in US baking sector from 1985 to 2010 period using OLS regression model. They considered total loans, lending rate and Real GDP per capital as independent variables. The finding reveals that real total loans have positive significant effect whereas interest rate and GDP per capital has negative significant association with NPLs.

Kablam (2010) assessed the determinants of banking system efficiency in Sub-Sahara Africa, and asks what, besides the degree of efficiency, explains the low level of financial development in the region. The sample of his study consisted of 137 banks in 29 African countries for the period of 1998-2002. Method of measurement of efficiency is stochastic frontier analysis for cost-effective frontier as well as the generalised method of moments for explaining financial development. Generalised method of moments makes it possible to take into account simultaneity bias reserve causality by using lagged independent variables as instruments. Variables included for cost-efficiency analysis included ratio of private loans to GDP, GDP per capita, share of rural population as well as capitalisation and bank size ownerships. Variables included for financial development were grouped into five categories, and these are market structure of the financial system, macroeconomic conditions, geography and legal tradition of countries, political environment and the regulation of financial system.

Yu and Gan (2010) examined the determinants of banking sector development in Malaysia using real income, real interest rates, trade openness and financial openness as explanatory variables. The study employed three models of banking sector development namely, liquid liabilities (M3), private sector credit and domestic credit. The analysis was made with ordinary least squares (OLS) method. The findings, were that real income encourages banking sector development. Consistent growth in GDP means that business entities respond to the demand of goods and services. This cycle will be brought about by increased lending and borrowing activities. The findings also suggest that financial openness have a negative impact on banking sector development.

Ali and Iva (2013) studied impact of bank specific factors on NPLs in Albanian banking system. They considered interest rate in total loan, credit growth, inflation rate, and real exchange rate and GDP growth rate as determinant factors. They used OLS regression model for panel data from 2002 to 2012 period. The finding reveals a positive association of loan growth and real exchange rate, and negative association of GDP growth rate with NPLs. However, the association between interest rate and NPL is negative but weak. And also inflation rate has insignificant effect on NPLs. 


\section{Section III: Research Methodology}

\subsection{Research Design}

The study is an ex-post facto research design in a linear specification via the partial adjustment approach making use of generalized theories and empirical studies

\subsection{Population and Sample}

This is purely time series study across banking sector in this regard, the population of the study covers the entire banking sector- their assets, profitability, credit default and other related variables. From this population of commercial banks in Nigeria, fourteen (14) banks were selected for the analyses, these sample were drawn randomly making use of bank variables of loan to deposit ratio, non-performing loan and interest margin span from 2002 to 2017. The Deposit Money banks selected are; First bank of Nigeria Plc, Sterling Bank Plc, Diamond Bank Plc, Access Bank Plc, Zenith Bank Plc, Unity Bank Plc, United Bank for Africa Plc, Union Bank of Nigeria, Guaranty Trust Bank Plc, Skye Bank Plc, WEMA Bank Plc, First City Monument Bank Plc, Fidelity Bank Plc and Ecobank Plc.

\subsection{Data and Data Collection Method}

The data employed in this study are typically secondary or already published data. These data are collected in times series and across banking sector which then turn it to panel data. Therefore data on loan to deposit ratio, nonperforming loan, return on equity was collected from annual publication of Nigeria Deposit Insurance Corporation (NDIC) and statistical bulletin of the Central Bank of Nigeria (CBN) all via their websites.

\subsection{Model Specification}

The model relevant to the study is adopted from the studies of Donia (2011); Yu \& Gan (2010); Benyah (2010); Seetanah et al., (2009); Ali and Iva (2013). This study introduced static OLS equation follows a standard ARDL model which is quoted in four models:

Following the research objectives, the functional form of the variable are hereby developed in form of

$$
\mathrm{Y}=\beta_{0}+\beta_{1} \mathrm{X}
$$$$
\text { roe }=\mathrm{f}(\mathrm{npc}, \text { inmg, } \mathrm{dtl})
$$$$
\text { roe }=\alpha_{0}+\alpha_{1} \text { npc }+\alpha_{2} \text { inmg }+\alpha_{3} \mathrm{dtl}+\mu
$$

Then put in panel format;

$$
\text { roe }_{\text {it }}=\alpha_{0}+\alpha_{1} \mathrm{npc}_{\mathrm{it}}+\alpha_{2} \mathrm{inmg}_{\mathrm{it}}+\alpha_{3} \mathrm{dtl}_{\mathrm{it}}+\mu_{\mathrm{it}}
$$

Equation (3.4) is the general model specification for objective. This static model assumes that all the variables are well behaved. That is, each of the variables is stationary at order zero.

\subsubsection{Analytical Variables}

\section{Dependent Variables}

Return on Equity (roe): This represents the rate of return received from equity invested in banks. It is the amount of net income returned as a percentage of shareholders equity. Return on equity measures profitability by revealing how much profit a bank can generate with the money shareholders have invested.

\section{Independent Variables}

Nonperforming Loan (npcs): These are loans that are outstanding both in its principal and interest for a long period of time contrary to the terms and conditions under the loan contract. Thus, the amount of non-performing loan represents the quality of bank assets (Tseganesh, 2012).

Deposit to Loan Ratio (dtl): This ratio examines bank liquidity by measuring the funds that a bank has utilized into loans from the collected deposits. It demonstrates the association between loans and deposits. Besides, it provides a measure of income source and also measures the liquidity of bank asset tied to loan (Makri et al.2014)).

Net Interest Margin (int): Lending rates are one of the primary economic determinants of NPCs and PCs. Interest rate spread is a measure of profitability between the cost of short term borrowing and the return on long term lending. Interest rate spread affect performing assets in banks as it increases the cost of loans charged on the borrowers (Joseph, 2011). While Net interest margin is a measure of the difference between the interest income generated by commercial banks and the amount of interest paid out to depositors relative to the amount of their (interest-earning) assets. 
Table 3.1 A priori Expectation

\begin{tabular}{|l|l|l|l|}
\hline Dependent variable & Explanatory Variables & $\begin{array}{l}\text { Expected } \\
\text { Sign }\end{array}$ & Decision \\
\hline $\begin{array}{l}\text { Return on Equity } \\
\text { (roe) }\end{array}$ & $\begin{array}{l}\text { Non-performing Loans } \\
\text { (NPLs) }\end{array}$ & - & $\begin{array}{l}\text { Rise in Non-performing Loans will lead } \\
\text { to decrease Return on Equity }\end{array}$ \\
\cline { 3 - 5 } & Deposit to Loan Ratio (dtl) & + & $\begin{array}{l}\text { Rise in Deposit to loan ratio will lead to } \\
\text { increase Return on Equity }\end{array}$ \\
\cline { 2 - 4 } & Net Interest Margin (int) & + & $\begin{array}{l}\text { Rise in Net Interest Margin increases } \\
\text { Return on Equity }\end{array}$ \\
\hline
\end{tabular}

Source: Author, 2018

\subsection{Limitations of the Methodology}

The model is a single equation approach to cointegration and it is only applicable to variables with mixed integrations but none must be I (2) variable. Also, the model must be weakly stationary or ergodic and the residuals must follow a Gaussian process. Thus, the model is developed to take care of the weakness of the multivariate equation approach to co-integration which stipulates that all the variable series must be I (1).

\subsection{Descriptive Analyses}

\subsubsection{Presentation of Data on Panel and Time series Variables}

The raw data on the variables employed for this study are presented in Appendix I and II respectively for the panel data variables and time series variables:

Various statistics tools were employed to examine the shapes of the distribution of these data and to check whether the data series follow a Gaussian process. The statistics are Jaque Bera (JB), Lilliefors (D), Cramer-von Mises (W2), Watson (U2), and Anderson-Darling (A2). Tables 3.2 present the value of these statistics in respect of each variable using time series and panel data.

Table 3.2: Showing Statistical Descriptive Results for Time Series Data

\begin{tabular}{|l|l|l|l|l|}
\hline Statistic & Roe & Npls & inmg & dtl \\
\hline Skewness(Sk) & 0.225971 & 1.584134 & 0.011390 & 0.460094 \\
\hline Kurtosist (Kt) & 1.422537 & 4.470454 & 3.146787 & 4.053464 \\
\hline Jarque-Bera (JB) & $4.038964(0.13)$ & $18.30023(0.00)$ & $0.033098(0.98)$ & $2.934797(0.23)$ \\
\hline Lilliefors (D) & $0.279574(0.00)$ & $0.27815(0.00)$ & $0.12924(>0.1)$ & $0.103599(>0.1)$ \\
\hline Cramar-Von-Misses (W2) & $0.444866(0.00)$ & $0.709152(0.00)$ & $0.094766(0.13)$ & $0.07592(0.23)$ \\
\hline Watson(U2) & $0.442572(0.00)$ & $0.628273(0.00)$ & $0.094217(0.11)$ & $0.075846(0.20)$ \\
\hline Anderson-Darling (A2) & $2.525558(0.00)$ & $3.639893(0.00)$ & $0.599236(0.11)$ & $0.537748(0.16)$ \\
\hline
\end{tabular}

Source: Author's Computation (2019)

Time series annual data were collected on net interest margin (inmg), non-performing loans (Npls), and Return on equity (roe) for a period of 12 years (2006 to 2017). As shown in table 3.2, the coefficient of skewness in each of the variables is approximately larger than zero $(0.23,1.58,0.01$ and 0.46 respectively for roe, Npls, inmg and dtl, indicating that all the variables are positively skewed, and asymmetric in nature. This simply means throughout the sampling period, the raw data exhibited much more low values than high value. The kurtosis values are 1.422537, 4.470454, 3.146787, and 4.053464 respectively for roe, Npls, inmg and dt. This means exchange rate has low volatility of volatility, and it is plytokurtic, with flat tail. While inflation, interest rate, non-performing loan and performing loan are leptokurtic with high volatility of volatility. This leptokurtic characteristic suggests that in future time, these variables would manifest high values or there would be occasional outliers in the future. The probability values of $\mathrm{D}$, W2, U2 and A2 are smaller than 5 percent significant level. This suggests that the preposition that exchange rate follows a normal distribution is only supported by the JB test. Hence, the normality hypothesis is rejected and it is affirmed that the variables series do not follow the pattern of a normal distribution. 


\section{Table 3.3: Showing Statistical Descriptive Results for Panel Data}

$\begin{array}{lllll}\text { Statistic } & \text { Roe } & \text { Npls } & \text { Dtl } & \text { Inmg } \\ \text { Skewness(Sk) } & -3.137712 & 6.533343 & 4.879167 & 6.632394 \\ \text { Kurtosist (Kt) } & 39.20210 & 63.40698 & 33.53594 & 56.23557 \\ \text { Jarque-Bera (JB) } & 9449.810(0.00) & 26738.19(0.00) & 7193.681(0.00) & 21069.86(0.00) \\ \text { Lilliefors (D) } & 0.32993(0.00) & 0.23262(0.00) & 0.25483(0.00) & 0.312895(0.00) \\ \text { Cramar-Von-Misses (W2) } & 5.339898(0.00) & 2.86967(0.00) & 3.483063(0.00) & 5.370788(0.00) \\ \text { Watson(U2) } & 5.335957(0.00) & 2.672817(0.00) & 3.194539(0.00) & 5.085597(0.00) \\ \text { Anderson-Darling (A2) } & 26.23006(0.00) & 19.63959(0.00) & 18.81105(0.00) & 32.13157(0.00)\end{array}$

Source: Author's Computation (2019)

Table 3.3 provides the summary statistics on net interest margin (inmg), nonperforming loans (npls), return on equity (ROE) and Deposit to Loan Ratio (dtl). Approximately, the coefficients of skewness are -3.14, 6.53, 4.88, and 6.63, for roe, npls, dtl and inmg respectively. All of these variables have long tail to the left except ROE that has long tail to the right. This means ROE increases much more on high values than small values over the sampling period 2002 to 2017, but npls increase less on high values than small values. The kurtosis values are quite asymptotic for each of the variable. Infact the lowest kurtosis value recorded is 33.54 (for $\mathrm{dtl}$ ). There is high tendency that these variables would increase in values or exhibit outliers in the future. These outliers are further justified by the distribution pattern revealed in the batteries of normality tests. The probability values for JB, D, W2, U2 and D2 for each variable is smaller than the alpha value at 1 percent, meaning that these entire variables are not Gaussian in their raw levels. This is not a serious problem since the sample size is large and differencing transformation can remove abnormal trends or outliers. In addition, graph plots are used to illustrate the pattern of these data.

\subsection{Correlation analysis}

Table 3.4 below shows the correlation analysis results among the pairs of the variables.

Table 3.4 Correlation analysis results

$\begin{array}{lllll} & \text { Roe } & \text { Npls } & \text { Inmg } & \text { Dtl } \\ \text { Roe } & 1.000000 & & & \\ \text { Npls } & 0.940823 & 1.000000 & & \\ \text { Inmg } & 0.859721 & 0.901835 & 1.000000 & \\ \text { Dtl } & 0.910442 & 0.881650 & 0.753585 & 1.000000\end{array}$

Source: Eview 7.0 output

The results of the correlation analysis show that all the variables (dependent and independent) are highly positively correlated with each other.

\subsection{Stationarity test results}

Since, most time series data exhibit a non-stationary characteristics and the presence of autocorrelation having the revealed in the level series estimates, the individual variables are passed through stationarity test, specifically unit root, in order to make the variables stationary and amenable for further analysis. The results are summarized on table 3.5 below.

Table 3.5 Summary of ADF Unit Root Test Results

\begin{tabular}{|l|l|l|l|l|}
\hline Variable & $\begin{array}{l}\text { ADF-Test statistic } \\
\text { @ 1st difference }\end{array}$ & Test Critical Values @ 5\% & $\begin{array}{l}\text { Order of } \\
\text { integration }\end{array}$ & Remarks \\
\hline Roe & -4.049229 & -3.403313 p-value $=0.0233$ & $\mathrm{I}(1)$ & Stationary \\
\hline Npls & -4.006689 & -3.403313 p-value $=0.0245$ & $\mathrm{I}(1)$ & Stationary \\
\hline Inmg & -7.059755 & -3.694851 -value $=0.0037$ & $\mathrm{I}(1)$ & Stationary \\
\hline Dtl & -3.962281 & -3.517595 p-value $=0.0313$ & $\mathrm{I}(1)$ & Stationary \\
\hline
\end{tabular}

Source: Author's compilation from Eview 7.0 output 
Table 3.5 above presents the summary results of the ADF unit root tests. The results show that the null hypotheses of a unit root test for first difference series for all the variables can be rejected at all the critical values indicating that the level series which is largely time-dependent and non-stationary can be made stationary at the first difference and maximum lag of one. Thus, the reduced form model follows an integrating order of I(1) process and is therefore a stationary process. It also reveals that the test of stationarity in the residuals from the level series regression is significant at all lags. Furthermore, this indicates that the regression is no more spurious. That is to say, all the variables are individually stationary and stable. At this level, all the t-statistic became significant at 5 percent.

Having established the stationarity of the individual variables, meaning the criteria for conducting co-integration has been met, the study now attempts to establish the stationarity of the linear combination of the variables to ascertain whether there could be a long-run equilibrium relationship between the dependent variables and the independent variables (that is, they form co-integrating equations). The study used Johansen co-integration test and the results are presented below.

\subsection{Johansen Co-Integration test results}

\section{Table 3.6 Johansen Cointegration test results}

Sample (adjusted): 2006Q4 2014Q4

Included observations: 33 after adjustments

Trend assumption: Linear deterministic trend

Series: Lroe, Npls Inmg dtl

Lags interval (in first differences): 1 to 2

Unrestricted Cointegration Rank Test (Trace)

\begin{tabular}{lclll}
\hline \hline $\begin{array}{l}\text { Hypothesized } \\
\text { of CE(s) }\end{array}$ & $\begin{array}{l}\text { No. } \\
\text { Eigenvalue }\end{array}$ & $\begin{array}{l}\text { Trace } \\
\text { Statistic }\end{array}$ & $\begin{array}{l}\text { 0.05 } \\
\text { Critical Value }\end{array}$ & Prob.** \\
\hline \hline None $*$ & 0.769888 & 117.9070 & 69.81889 & 0.0000 \\
At most 1* & 0.590056 & 69.42378 & 47.85613 & 0.0002 \\
At most 2* & 0.525168 & 39.99653 & 29.79707 & 0.0024 \\
At most 3 & 0.350403 & 15.41833 & 15.49471 & 0.0513 \\
At most 4 & 0.035186 & 1.182049 & 3.841466 & 0.2769
\end{tabular}

Trace test indicates 3 cointegrating eqn(s) at the 0.05 level

* denotes rejection of the hypothesis at the 0.05 level

**MacKinnon-Haug-Michelis (2019) p-values

Unrestricted Cointegration Rank Test (Maximum Eigenvalue)

\begin{tabular}{|c|c|c|c|c|}
\hline $\begin{array}{l}\text { Hypothesized No. } \\
\text { of CE(s) }\end{array}$ & Eigenvalue & $\begin{array}{l}\text { Trace } \\
\text { Statistic }\end{array}$ & $\begin{array}{l}0.05 \\
\text { Critical Value }\end{array}$ & Prob.** \\
\hline None $*$ & 0.769888 & 48.48325 & 33.87687 & 0.0005 \\
\hline At most $1^{*}$ & 0.590056 & 29.42725 & 27.58434 & 0.0287 \\
\hline At most $2 *$ & 0.525168 & 24.57821 & 21.13162 & 0.0157 \\
\hline At most 3 & 0.350403 & 14.23628 & 14.26460 & 0.0505 \\
\hline At most 4 & 0.035186 & 1.182049 & 3.841466 & 0.2769 \\
\hline
\end{tabular}

Max-eigenvalue test indicates 3 co integrating eqn(s) at the 0.05 level

$*$ denotes rejection of the hypothesis at the 0.05 level

**MacKinnon-Haug-Michelis (2019) p-values

Source: Compiled from eviews 7.0 output.

The results of the Johansen co-integration test presented above indicate at least three co-integration equations for both trace and max-eigen statistics. The result, therefore, confirms the existence of co-integration among the variables. Consequently, we can conclude that there exists a long run equilibrium relationship between non-performing loans on Deposit Money Banks' profitability in Nigeria. 


\subsection{Error correction mechanism (ECM)}

Having established long run equilibrium relationship between the dependent and independent variables, the study now switches over to establish short run relationships between the dependent and independent variables using the error correction mechanism. Since the variables were found to be stationary at first difference, the error correction mechanism is tested using first differenced series. The results are presented below.

Table 3.7 Error correction mechanism (ECM)

Dependent Variable: D(Roe)

Method: Least Squares

Date: 10/26/19 Time: 07:34

Sample (adjusted): 2006Q2 2014Q4

Included observations: 35 after adjustments

\begin{tabular}{lllcc}
\hline \hline \multicolumn{1}{c}{ Variable } & Coefficient & Std. Error & t-Statistic & Prob. \\
& & & & \\
C & 0.080265 & 0.057367 & 1.399151 & 0.1724 \\
Npls & 0.248257 & 0.137062 & 1.811282 & 0.0805 \\
Inmg & 0.373693 & 0.138755 & 2.693188 & 0.0116 \\
Dtl & -0.028338 & 0.207100 & -0.136831 & 0.8921 \\
ECM(-1) & -0.267611 & 0.127708 & -2.095495 & 0.0450 \\
\hline \hline \multicolumn{2}{r}{ R-squared } & 0.301406 & Mean dependent var & 0.181737 \\
Adjusted R-squared & 0.180958 & S.D. dependent var & 0.258549 \\
S.E. of regression & 0.233989 & Akaike info criterion & 0.087722 \\
Sum squared resid & 1.587778 & Schwarz criterion & 0.354353 \\
Log likelihood & 4.464874 & Hannan-Quinn criter. & 0.179763 \\
F-statistic & 2.502385 & Durbin-Watson stat & 1.767529 \\
Prob(F-statistic) & 0.053121 & & \\
\hline \hline
\end{tabular}

Source: Eview 7.0 output

The results of the error correction model (ECM) on the table above shows that ECM is appropriate signed with a negative co-efficient of -0.267611 and a probability of 0.045 , which is significant. Since the ECM is both negative and significant, it shows that the present value of Roe adjusts rapidly to changes in Npls, Inmg, and dtl, respectively. The ECM value of -0.267611 shows a feedbacks of about $26.76 \%$ from the previous period disequilibrium of the present level of Roe in the determination of causality between the past level of Roe and the present and past level of Npls, Inmg, and Dtl. The coefficient of multiple determinations denoted as $\mathrm{R}^{2}$ shows that $30.14 \%$ variation in Roe can be explained by the combined effect of Npls, Inmg, and Dtl while the remaining $69.86 \%$ is being included by the stochastic error term. The Durbin Watson statistics of 1.67 shows that the presence of autocorrelation in the model is inconclusive as the Durbin Watson statistics falls under the positive side of the inconclusive region.

The study further proceeds to residual diagnostic tests such as serial correlation LM test, heteroskedasticity test, and histogram normality test to ascertain the status of the residuals as basis for making inferences about the model.

Table 3.8 Serial correlation LM test results

Breusch-Godfrey Serial Correlation LM Test:

\begin{tabular}{lccc}
\hline \hline F-statistic & 0.978013 & Prob. F(2,27) & \multirow{2}{*}{0.3890} \\
Obs*R-squared & 2.364307 & Prob. Chi-Square (2) & 0.3066 \\
\hline \hline
\end{tabular}

Source: Evie w 7.0 output Durbin-Watson stat $=2.0007$ 
The observed r-squared statistic on the Breusch-Godfrey serial correlation LM test result shows a statistic of 2.364307 and a probability chi-square of 0.3066 , meaning, we cannot reject the null hypothesis, that there is no serial correlation among the residuals. Also, the Durbin Watson is 2.00 which indicate absence of autocorrelation. The study can conclude that residuals are not serially correlated.

Table 3.9 Heteroskedasticity test results

Heteroskedasticity Test: Breusch-Pagan-Godfrey

\begin{tabular}{cccc}
\hline \hline F-statistic & 0.525875 & Prob. F(5,29) & 0.7547 \\
Obs*R-squared & 2.909579 & Prob. Chi-Square(5) & 0.7139 \\
Scaled explained SS & 1.533280 & Prob. Chi-Square(5) & 0.9092 \\
\hline \hline
\end{tabular}

Source: Evie w 7.0 output $\quad$ Durbin-Watson stat $=1.75$

The observed r-squared statistic on the Breusch-Pagan-Godfrey heteroskedasticity test result shows a statistic of 2.909579 and a probability chi-square of 0.7139 , meaning, we cannot reject the null hypothesis, that there is no heteroskedasticity among the residuals. Also, the Durbin Watson is 1.75 , which is close to 2.00 indicating absence of autocorrelation. The study can conclude that the residuals are not heteroskedastic.

\subsection{Test of Hypotheses}

Having established the validity of the error correction model, the formulated hypotheses can now be tested and inferences made based on the model.

$\mathbf{H}_{01}$ : There is no significant relationship between non-performing loans on Deposit Money Banks' profitability in Nigeria.

The results on table 3.7 above show that Npls has a t-statistic of 1.811282 with a probability value of 0.0805 , which indicates that it is statistically significant at 5 percent. The null hypotheses cannot, therefore, be rejected; but accepted. This means that Non Performing Loans (Npls) does not have significant impact on the profitability of commercial banks in Nigeria. The impact is, however, significant at 10 percent level.

Also in the table Inmg has a t-statistic of 2.693188 with a probability value of 0.0116 , which indicates that it is statistically significant at 5 percent. The null hypotheses can, therefore, be rejected. This means that Net Interest Margin (Inmg) have a significant influence on the profitability of commercial banks in Nigeria.

Table 3.7 shows that Dtl has a t-statistic of -0.136831 with a probability value of 0.8921 , which is statistically insignificant. The null hypothesis cannot, therefore, be rejected; but accept to the effect that Deposit to Loan Ratio (Dtl) have no significant relationship with the profitability of commercial banks in Nigeria.

Overall, in the table F-statistic is 2.502385 with a probability value of 0.053121 , which is significant at 5 percent. This indicates that the combined effect of independent variables is significant to the profitability of commercial banks in Nigeria.

\subsection{Discussions of Findings}

The study provides fresh findings on the impact of non-performing loans on Deposit Money banks' performance in Nigeria, since the study is an extension of the existing studies; only few of its findings that is in tandem or contrary to current positions in the literature. It is further documented that historical return on equity has inverse effects on nonperforming loan in the short run, while historical nonperforming loan, net interest margin and return on total asset influence nonperforming loan positively in the short run. In contrast to these findings, Dayong Jing., David and Ali, (2016) revealed that nonperforming loan is negatively influenced by bank specific factors. This position was supported by the studies of Akinlo, and Mofoluwaso, (2014) who confirmed inverse relationship.

Many studies did not really capture long run relationship, since they focused on fixed effects models (Raluca-Ioana and Oaneab, 2014). Nevertheless, the test of long run relationship reveals that nonperforming loan and bank specific factors maintains long run relationship. In the same vain, it was affirmed that long run relationship between nonperforming loan, exchange rate, inflation and net interest margin in Nigeria. So also, evidence of long run relationship between/among performing loan, net interest margin, inflation and exchange rate is documented in this study. 


\section{Section Four: Summary of Findings and Recommendations}

This section of this study originates from the specific issues, which has been addressed empirically in section three. It is rooted in the link between the major findings and the objectives proposed for the study. The scope of the section therefore covers the discussion of findings, summary of findings, and policy implication of findings.

\subsection{Summary of Findings}

In this study, the author investigates the impact of non-performing loans on Money deposit banks' performance in Nigeria. Three specific factors were identified of banks (net interest margin, deposit to loan and non-performing loans) against return on equity that represent money deposit banks

It was empirically discovered that return on equity maintains long run association with non-performing loans, net interest margin and deposit to loan. This means that these variables are long run determinant of Return on equity.

It was also discovered that long run causality or influence runs jointly from non-performing loans, Deposit to loan and net interest margin. Surprisingly, while long run influence flows from net interest margin, return on equity and nonperforming loan to return on equity influence does not run from return on equity to these variables, except that there is short run dynamic between these variables. It was also discovered that within the purview of short run dynamic, net interest margin and return on equity increase with a rise in nonperforming loan. Nevertheless, return on equity decreases with any rise in nonperforming loan.

\subsection{Conclusion}

Foremost, it was concluded that there is existence of short run and long run dynamic relationships between nonperforming loan, and net interest margin, this set of variables are potentially influential in driving or interacting with return on equity in both the short run and long run economic situations. It is therefore concluded that influence/causality in the long run runs from nonperforming loans return on equity. Furthermore, forces of interconnectedness run from net interest margin, return on equity and return on total asset to nonperforming loan. Therefore, the future state of nonperforming loans is determined by the intrinsic factors and extrinsic factors of the banking sector.

In the same vein, interest rate margin, nonperforming loans and deposit to loans are sensitive to return on equity. However, the study concludes that the most variable is net interest margin.

\subsection{Recommendations}

In view of the major findings, the researcher proposes the following policies to be adopted in the banking sector.

1. Flexible credit policy- An effective credit policy that is reflected in flexible tenure, restructuring of credit terms and conversion should be adopted in the banking sector. This policy could help reducing the tempo of nonperforming loan, such that as return on equity is increasing, the possibility of default would decline considerably.

2. Wholesome interest rate policy- A wholesome interest rate policy is premised on the margin between deposit rate and lending rate. An optimum margin is required to trigger performing loan, and to reduce nonperforming loan significantly.

3. Bank focused macroeconomic policy-In less developed countries like Nigeria, banks are the "heart beat" of the economies. Therefore, Nigerian monetary authority should articulate exchange rate policy or policy of price stability that could create enabling market for banks to drive effectively.

\section{References}

Akinlo, O. and Mofoluwaso, E. (2014). Determinants of non-performing loans in Nigeria. IBFR Accounting and Taxation, Vol. 6 (2).

Ali, S. and Iva, S. (2013) Impact of Bank Specific Variables on the Non -Performing Loans Ratio Albanian Banking System, Journal of Finance and Accounting Vol. 4(7).

Atoi, V. N (2018). Non-performing Loan and its Effects on Banking Stability: Evidence from National and International Licensed Banks in Nigeria. CBN Journal of Applied Statistics Vol. 9 (2).

Bekaert, G.; Harvey C.R and Lundblad, C. (2005). Does financial liberalization spur growth. Journal of Financial Economics: Vol. 3(55).

Bertrand, M.; Schoar A, and Thesmar, D. (2007). Banking deregulation and industry structure: Evidence from the french banking reforms of 1985. The Journal of Finance, Vol. 62(2): 597-628. 
Central Bank of Nigeria (2016). Understanding monetary policy and Financial concepts.

Dayong Z., Jing C., David G. D., and Ali M. K. (2016). Non-performing loans, moral hazard and regulation of the Chinese commercial banking system. Journal of Banking and Finance, Vol. 63.

Ekanayake, E.M. N.N. and Azeez A.A., (2015) Determinants of Non- Performing Loans in Licensed Commercial Banks: Evidence from Sri Lank. Asian Economic and Financial Review 5 (6) 868-882

Ekanayake E. and Azeez A.A. (2015). Determinants of nonperforming loans in licensed commercial banks: evidence from Sri Lanka. Asian economic and Financial Review, Vol. 5 (6).

Etale L. M., Ayunku,P. E., and Etale, E. L. M. (2016). The impact of Non-performing Loans and Bank Performance in Nigeria. International Journal of Humanities and Social Science Invention Vol. 5 (4).

Guiso, L., Sapienza P. and Zingales, L. (2002). Does local financial development affect economic growth? National Bureau of Economic Research Working Paper 8922

Habibullah, M.S. and Eng, Y.K. (2006). Does financial development cause economic growth? A panel data dynamic analysis for the Asian developing countries. Journal of the Asia Pacific Economy. Vol.11(4).

Honohan, P. (Eds.), (2004). Financial development, growth, and poverty: How close are the links? London Palgrave.

Levine, R. (1997). Financial development and economic growth: Views and agenda. Journal of Economic Literature, Vol.35(2).

Levine, R.; Loayza N. and Beck, T. (2000). Financial intermediation and growth: Causality and causes. Journal of monetary Economics, Vol. 46(1).

Morck, R.; Wolfenzon D.N. and B. Yeung (2005). Corporate governance, economic entrenchment and growth. Journal of Economic Literature.

Ndebbio, J.E. (2004). Financial deepening, economic growth and development: Evidence from selected Sub-Saharan African Countries. AERC Working Papers, 142.

Nzotta, S. and Okereke, E. (2009). Financial deepening and economic development of Nigeria: An empirical investigation. African Journal of Accounting, Economics, Finance and Banking Research, Vol.5(5).

Ojo, J. A.T. and Somoye R.O.C. (2016). The Impact of Commercial Banks Non-performing Loans on Financial Development in Nigeria. International Journal of Economics and Financial Issues, Vol. 12.

Okonjo, I. N and K. Osafo, P. (2007). Nigeria's economic reforms: Progress and challenges. Brookings Global Economy and Development Working Paper (6)

Onwe B. U. (2015). The relationship between liquidation and banking industry stability in Nigeria. International Journal of Small Business and Entrepreneurship Research Vol. (7)

Raddatz, C. (2006). Liquidity needs and vulnerability to financial underdevelopment. Journal of financial economics. Vol. 80(3): 677-722.

Raluca-Ioana, D. and Oaneab, D. (2014). The main determinants of bank's stability. evidence from Romanian banking sector. Procedia Economics and Finance Vol. 16.

Saba I. Kouser R. and Azeem M., (2012). Determinants of Nonperforming Loans: Case of US Banking Sector, The Romanian Economic Journal, Vol. XV (44).

Sere-Ejembi, A., Udom, I.S., Salihu, A., Atoi, N.V., and Yaaba, B.N., (2014). Developing banking system stability index for Nigeria. CBN Journal of Applied Statistics, Vol. 5 (1).

Skarica B. (2014) Determinants of Non-Performing Loans in Central and Eastern European countries, Financial Theory and Practice 38(1) 37-59

Sohaib I K. and Naveed, QM. (2016). The Determinants of Credit Risk in Commercial Banks of Pakistan. Journal of Poverty, Investment and Development, Vol.25.(65).

Vasiliki M., Athanasios T. and Athanasios B. (2014): Determinants of nonperforming loans: the case of eurozone. PANOECONOMICUS, Vol. 2, 